\title{
Aerobic Degradation of Fluoranthene, Benzo(b)Fluoranthene and Benzo(k) Fluoranthene by Aerobic Heterotrophic Bacteria- Cyanobacteria Interaction in Brackish Water of Bodo Creek
}

\author{
Ichor Tersagh*, Ebah EE and Azua ET
}

Department of Biological Sciences, University of Agriculture, Makurdi, Nigeria

\begin{abstract}
The study aimed at ascertaining the biodegradability of polyaromatic hydrocarbons in the fate of fluoranthene, benzo(b)fluoranthene and benzo(k)fluoranthene by aerobic heterotrophic bacteria - cyanobacteria interaction in crude oil contaminated brackish water of Bodo creek. Samples of brackish water were spiked with known volume of Bonny Light crude oil and inoculated with aerobic heterotrophic bacteria and cyanobacteria isolated from crude oil contaminated waters of Bodo creek and monitored for 56 days. The PAHs investigated were quantified using GC-MS where as the bacteria and cyanobacteria isolates were identified on the basis of 16S rRNA gene sequence analysis. The initial quantity of fluoranthene on day 0 for the treatments of Aerobic heterotrophic bacteria (A) 0.43 Cyanobacteria (B) 0.061 , and a consortium of $A+B 0.24$, and the Control, (C) 0.26 ; Benzo(b)fluoranthene had 0.53 , $0.31,0.65$ and 0.66 whereas benzo(k)fluoranthene had $0.62,0.31,0.56$ and $0.69 \mathrm{mg} / \mathrm{l}$ respectively. There was an observed degradation of the HMW-PAHs which decreased and increased progressively from the treatments with exception of fluoranthene which remained at 0 from week 2 in all the treatment options. Biodegradation did not vary significantly with time in all the treatment options and the control.
\end{abstract}

Keywords: Petroleum hydrocarbons; Brackish water; Biodegradation

\section{Introduction}

Polycyclic aromatic hydrocarbons (PAHs) are reportedly toxic, ubiquitous, and organic compounds that can persist in the environment $[1,2]$ and are largely released into the environment due to incomplete combustion of fossil fuels [3]. Yu et al. [4] posited that fluoranthene is a major component of petroleum sludge; it is also reported to be a nonalternant high-molecular-weight PAH that has a five-member ring which has the same structure when compared with other compounds such as dibenzodioxin, dibenzofuran, acenaphthylene, carbazole, fluorene, and dibenzothiophene [2,5]. According to Mishra et al. [3] it is mutagenic, carcinogenic, teratogenic and hydrophobic in nature and binds strongly to soil particles with a restricted bioavailability. However, high-molecular-weight PAHs (HMW-PAHs), such as pyrene, benzo(a)pyrene and benzo(b)fluoranthene, are generally said to be recalcitrant and resistant to microbial attack due to their low solubility and bioavailability hence, highly persist in the environment and can bioaccumulate in organisms [6]. It is widely reported that, HMW PAHs are not easily soluble in water, electrochemically stable and can be acutely toxic, genotoxic and immunotoxic $[7,8]$ or are responsible for disruption hormones [9] based on circumstances and the mode of exposure. They are also implicated in bioconcentration, bioaccumulation and sometimes biomagnification through trophic transfers in terrestrial and marine food webs [10].

Fluoranthene has undergone degradation by bacteria previously as reported by researchers in the genera of Alcaligenes [11], Burkholderia [12], Mycobacterium [13], Pseudomonas [14], and Rhodococcus [15] Sphingomonas [16]. However, a few fluoranthene degraders were isolated from the marine environment and reported to belong to the genera; Ochrobactrum [17], Novosphingobium [18], Cycloclasticus [19] and Celeribacter [20]. Zhisong et al. that the degradation of both fluoranthene and pyrene was achieved faster by a consortium of Cycloclasticus sp. PY97M and Marinobacter nanhaiticus D15-8WT compared to individual strains. Dean-Ross et al. [21] reported on the capability of degradation of fluoranthene by Mycobacterium flavescens and Rhodococcus spp. with subsequent formation of 9-fluorenone-1carboxylic acid as a metabolite. Two Marinobacters, $M$. sedimentalis and M. falvimaris were isolated from hypersaline sabkhas due to their capability to grow on crude oil and were observed to have utilized Tween 80 and other individual aliphatic hydrocarbons ranging from $\mathrm{C}_{9}-\mathrm{C}_{40}$ as carbon sources in the presence of $6 \% \mathrm{NaCl}$ [22]. Dastgheib et al. [23] isolated a mixed culture (Qphe-SubIV) of Halomonas sp. and Marinobacter sp. from saline soils contaminated with hydrocarbon from five regions in Iran. The bacteria reportedly degraded several other PAHs as well as fluoranthene as the sole sources of carbon in the presence of $1-15 \% \mathrm{NaCl}$.

Benzo(b)fluoranthene and Benzo(k)fluoranthene are polycyclic aromatic hydrocarbons that have the chemical formula $\mathrm{C}_{20} \mathrm{H}_{12}$. They are colourless solids with poor solubility in most solvents. Impure samples can appear as off white. Benzo(b)fluoranthene is closely related to other isomeric compounds which include benzo(a)fluoranthene, benzo(e) fluoranthene, benzo(j)fluoranthene, and benzo(k)fluoranthene [24]. $\operatorname{Benzo}(k)$ fluoranthene as a member of the five-ring HMW PAH class was observed to resist biotransformation due to its molecular stability, hydrophobic nature and low water solubility, which is approximately $1 \mathrm{ug} \mathrm{\textrm {L } ^ { - 1 }}$ or less [25-27]. In the environment, it is present in polluted soils in parts per million range showing different persistence levels; hence

"Corresponding author: Ichor Tersagh, Department of Biological Sciences, University of Agriculture, Makurdi, Nigeria, Tel: +234(0)7039256061; E-mail: smartichor@uam.edu.ng

Received May 07, 2016; Accepted July 30, 2016; Published August 07, 2016

Citation: Tersagh I, Ebah EE, Azua ET (2016) Aerobic Degradation of Fluoranthene, Benzo(b)Fluoranthene and Benzo(k)Fluoranthene by Aerobic Heterotrophic Bacteria- Cyanobacteria Interaction in Brackish Water of Bodo Creek. J Pet Environ Biotechnol 7: 292. doi: 10.4172/2157-7463.1000292

Copyright: (C) 2016 Tersagh I, et al. This is an open-access article distributed under the terms of the Creative Commons Attribution License, which permits unrestricted use, distribution, and reproduction in any medium, provided the original author and source are credited. 
Citation: Tersagh I, Ebah EE, Azua ET (2016) Aerobic Degradation of Fluoranthene, Benzo(b)Fluoranthene and Benzo(k)Fluoranthene by Aerobic Heterotrophic Bacteria- Cyanobacteria Interaction in Brackish Water of Bodo Creek. J Pet Environ Biotechnol 7: 292. doi: 10.4172/21577463.1000292

it is included as one of the 16 pollutants on the U.S. Environmental Protection Agency's (EPA) Priority Pollutant List [28-31]. In animals, there are existing proves of carcinogenicity caused by benzo $(k)$ fluoranthene, and has also been classified as a group 2B carcinogen by the 'International Agency for Research on Cancer' in humans [32].

Zheng, Obbard and Cerniglia [33-35] reported removal of Benzo(b)fluoranthene and Benzo(k)fluoranthene among other HMWPAHs by some filamentous fungi, white rot fungi, basidiomycetes and deuteromycetes fungi more efficiently than bacteria. Sphingobium species strain KK22 biologically transformed benzo( $k$ )fluoranthene via the 8,9-carbon position which was the initial position of attack on the parent molecule. This type of attack is structurally analogous to initial 7,8-carbon position attack that was described for fluoranthene by other gram-negative and gram-positive species. The identification of the downstream products 9-hydroxy-fluoranthene-8-carboxylic acid and 1,8-naphthalic anhydride for instance, which may have occurred through 8,9-carbon position initial attack on the benzo $(k)$ fluoranthene molecule provides a clear evidence in support of biotransformation mechanism by microorganisms. The first ring fission event of the benzo $(k)$ fluoranthene molecule occurred by ortho-ring cleavage and resulted in 8-carboxyfluoranthenyl-9-propenic acid, a product that corresponded to $[\mathrm{M}-\mathrm{H}]^{-}=315$, and this is the first report of this product from PAH biodegradation [24]. Ichor et al. [1,36] reported on effective biodegradation of total petroleum hydrocarbons and mineralization of phenanthrene a LMW PAHs by the consortium of aerobic heterotrophic bacteria and cyanobacteria from Bodo creek respectively.

The present study aimed at ascertaining degradation of these HMWPAHs; fluoranthene, benzo(b)fluoranthene and benzo(k)fluoranthene from brackish water contaminated with petroleum hydrocarbons by the resident aerobic heterotrophic bacteria and cyanobacteria.

\section{Materials and Methods}

\section{Study area}

The study was carried out in crude oil contaminated brackish water body; Bodo creek which is located in Ogoni land in Gokana, LGA of Rivers State, in Niger Delta region.

\section{Media and incubation conditions}

The method for BG-11 medium preparation described by Ichor et al. [36] was adopted.

\section{Enumeration and molecular characterization of cyanobacteria and aerobic heterotrophic bacteria}

Samples of brackish water and sediment obtained from crude oil contaminated Bodo creek in Rivers State, Nigeria. BG-11 aqueous medium was prepared and inoculated with water and filterates from sediment samples using different medium- water volume ratio as described in Ichor et al. [1]. The set up was supplemented with ciprofloxacin and nystatin in order to avoid bacteria and fungi growth. Incubation was done by using a cotton wool to cork the Erlenmeyer flask and exposed to natural sunlight for $12 \mathrm{hr}$ and darkness for 12 $\mathrm{hr}$ for 14 days under ambient temperature as described by Ichor et al. [1]. This was shaken twice every day to prevent sedimentation of the nutrients in BG-11 medium. Polymerase chain reaction was performed on the DNA extracted directly from the samples using Universal primers for cyanobacteria CYA 106F ( CGC ACG GGT GAG TAA CGC GTG A and CYA 359F(GGG GAA TYT TCC GCA ATG GG) with a 40 nucleotide GC clamp ( $5^{1}$ CGC CCG CCG CGC CCC GCG
CCG GTC CCG CCG CCC CCG CCC G $3^{1}$ ) on the $5^{1}$ end forward primer and CYA 781R (equimolar mixture of CYA781Ra (GAC TAC TGG GGT ATC TAA TCC CAT T) and CYA 781Rb ( GAC TAC AGG GGT ATC TAA TCC CTT T) reverse primers for amplification of a segment of cyanobacterial 16S rRNA gene were synthesized.

The DNA of aerobic heterotrophic bacteria were extracted directly from water samples and filterates from sediment samples and polymerase chain reaction was performed using universal primers used for bacteria; Eub 27F (51-31. AGA GTT TGA TCC TGG CTC AG) forward primer and Eub 1492R (51-31. ACG GCT ACC TTG TTA CGA CTT) for reverse primers. Purification of the PCR sequence products was done using $2 \mathrm{M}$ sodium acetate wash technique before sequencing. Sequences obtained were compared with known sequences in the Gen Bank using the basic local alignment search tool (BLAST) of the National Centre for Biotechnology Information (NCBI) [36]. Phylogenetic tree was constructed based on almost complete 16S rRNA gene sequences (>1300 bp) using MEGA 6.5 software by applying the various methods integrated in it.

\section{Preparation of inoculum and biodegradation experiment}

Aerobic heterotrophic bacteria aliquot was prepared via transfer of a loopful of $24 \mathrm{hr}$ old culture of each isolate into $400 \mathrm{ml}$ of sterilized nutrient broth contained in $500 \mathrm{ml}$ Erlenmeyer flask and incubated for $24 \mathrm{hrs}$. This was supplemented with $\mathrm{CuSO}_{4}$ and nystatin to prevent the growth of cyanobacteria and fungi [1].

The different treatment options of brackish water and sediment filterate samples labelled AHB and CB were prepared asceptically and $200 \mathrm{ml}$ each of aerobic heterotrophic bacteria and cyanobacteria aliquot was transferred to $500 \mathrm{ml}$ of sterile distilled water in two separate 1000 $\mathrm{ml}$ flask, $\mathrm{AHB}+\mathrm{CB}$ consortium was prepared and standardized with 0.5 M Macfarland solution as reported by [36]. The water containers for the experimental set up were filled with 11 litres of water and labeled $\mathrm{AHB}, \mathrm{CB}, \mathrm{AHB}+\mathrm{CB}$ and $\mathrm{C}$ for the control and spiked with $32300 \mathrm{ppm}$ of sterile Bony light crude oil sample obtained from shell petroleum development company. Treatment of the set up with ciprofloxacin, nystatin and $\mathrm{CuSO}_{4}$ respectively was done as reported in Ichor et al. [35]

\section{Results}

Fluoranthene, benzo(b)fluoranthene and benzo(k)fluoranthene degradation by aerobic heterotrophic bacteria, cyanobacteria and their consortium was monitored using Agilent 7890 GC-MS model. Fluoranthene disappeared after the second week of monitoring in all treatments. Benzo(k)fluoranthene reduced to 0.04 for A, 0.01 (B); 0.02 $(\mathrm{A}+\mathrm{B})$ and $0.01 \mathrm{mg} / \mathrm{L}$ for the control in week 8 . Benzo(k)fluoranthene degraded to $0.04(\mathrm{~A}) ; 0.02(\mathrm{~A}+\mathrm{B})$ and $0.01 \mathrm{mg} / \mathrm{L}$ for $\mathrm{B}$ and control respectively. The result showed a decrease in the quantity of the PAHs studied for all the treatment options on the last day of the experiment though with observed fluctuations for benzo(b) fluoranthene and benzo(k)fluoranthene throughout the period monitored (Figures 1-4). There was no observed significant difference in the biodegradation of the HMW-PAHs monitored with time ( $p>0.05)$. Figure 5 is the unrooted phylogenetic tree which shows the relatedness of aerobic heterotrophic bacteria and cyanobacteria present during the biodegradation experiment. The most dominant bacteria were the Bacillus species.

\section{Discussion}

Biodegradation of fluoranthene, benzo(b)fluoranthene and benzo(k)fluoranthene monitored from Petroleum hydrocarbon contaminated brackish waters of Bodo creek was monitored using 
Citation: Tersagh I, Ebah EE, Azua ET (2016) Aerobic Degradation of Fluoranthene, Benzo(b)Fluoranthene and Benzo(k)Fluoranthene by Aerobic Heterotrophic Bacteria- Cyanobacteria Interaction in Brackish Water of Bodo Creek. J Pet Environ Biotechnol 7: 292. doi: 10.4172/21577463.1000292

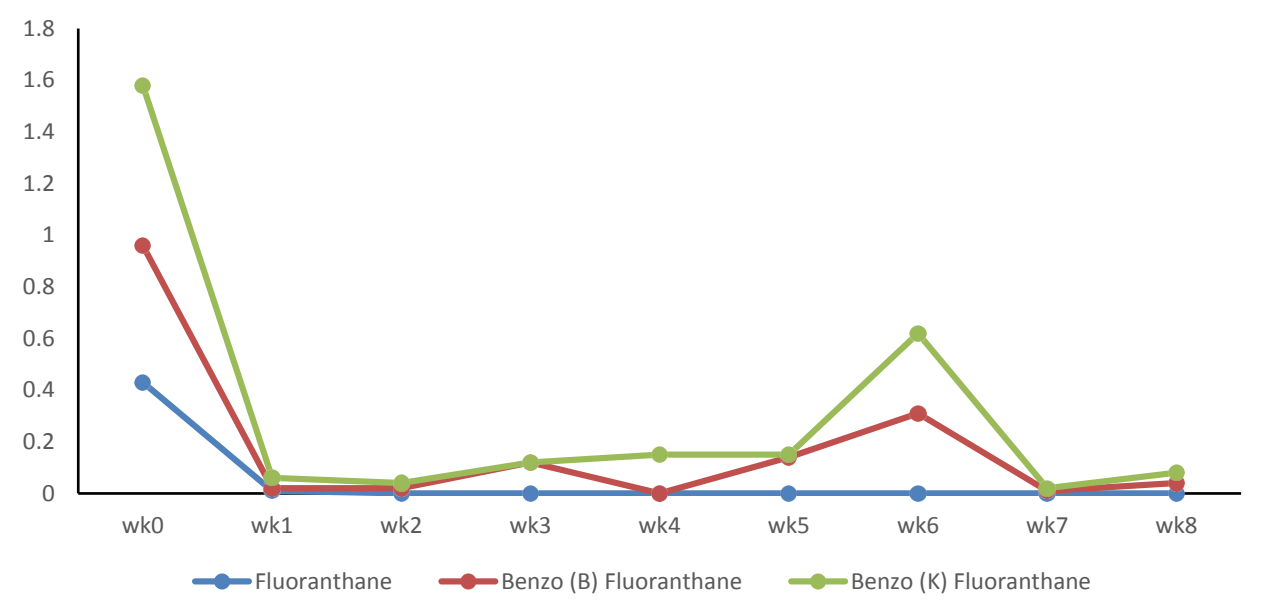

Figure 1: Degradation of fluoranthene, benzo(b)fluoranthene and benzo(k)fluoranthene by aerobic heterotrophic bacteria.

Sample B

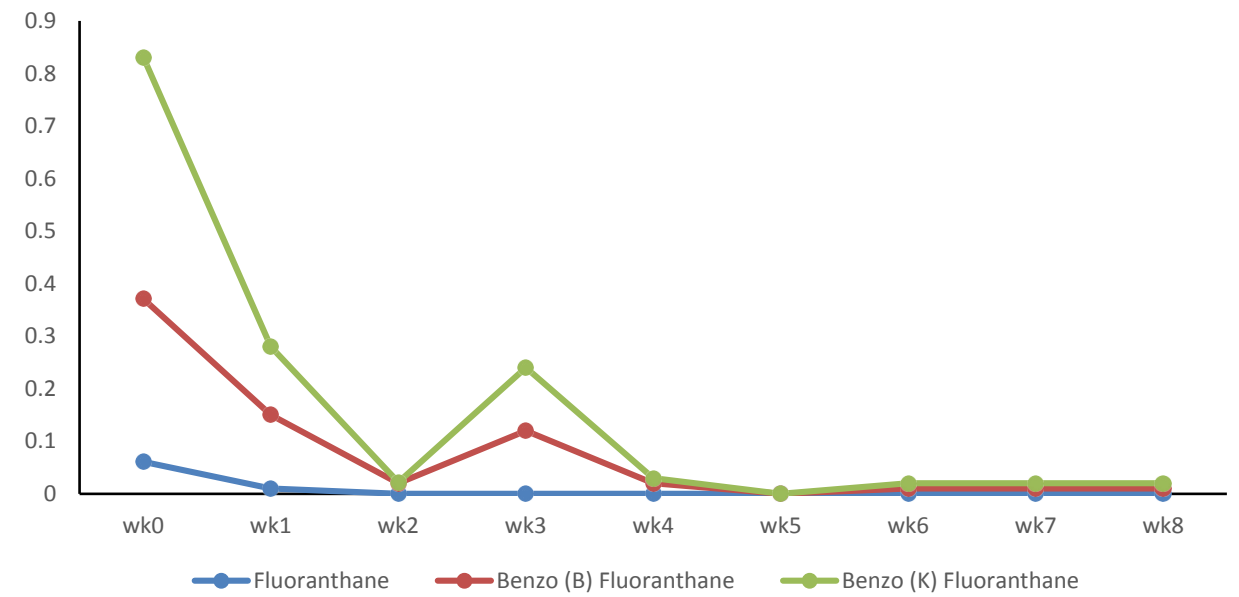

Figure 2: Degradation of fluoranthene, benzo(b)fluoranthene and benzo(k)fluoranthene by cyanobacteria.

Sample A + B

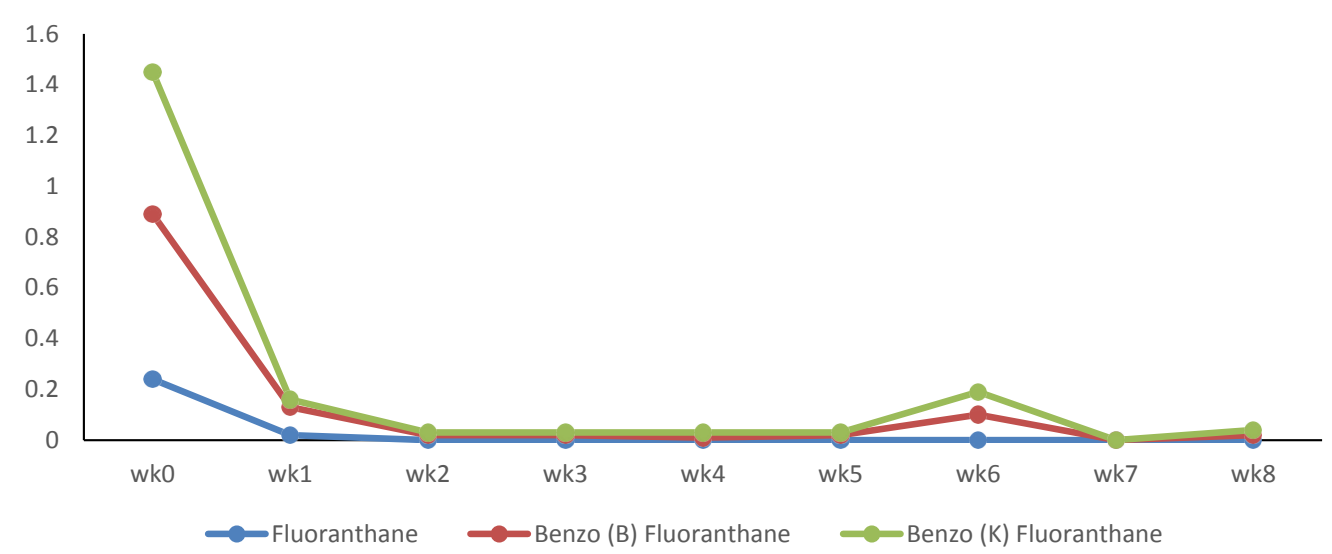

Figure 3: Degradation of fluoranthene, benzo(b)fluoranthene and benzo(k)fluoranthene by consortium of aerobic heterotrophic bacteria and cyanobacteria. 
Citation: Tersagh I, Ebah EE, Azua ET (2016) Aerobic Degradation of Fluoranthene, Benzo(b)Fluoranthene and Benzo(k)Fluoranthene by Aerobic Heterotrophic Bacteria- Cyanobacteria Interaction in Brackish Water of Bodo Creek. J Pet Environ Biotechnol 7: 292. doi: 10.4172/21577463.1000292

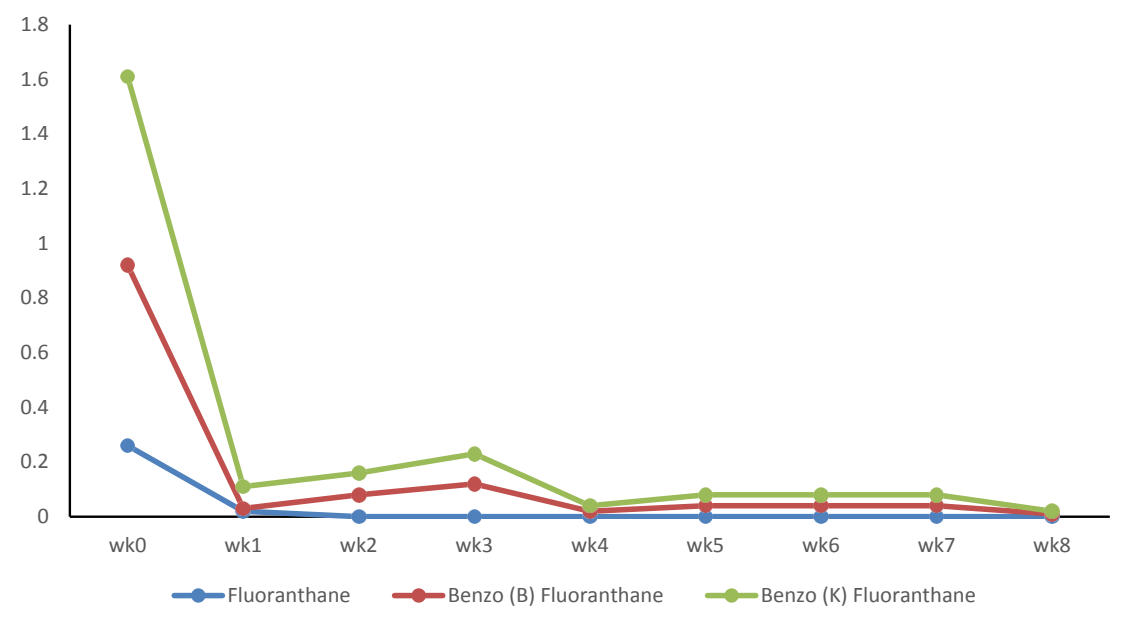

Figure 4: Degradation of fluoranthene, benzo(b)fluoranthene and benzo(k)fluoranthene by control.

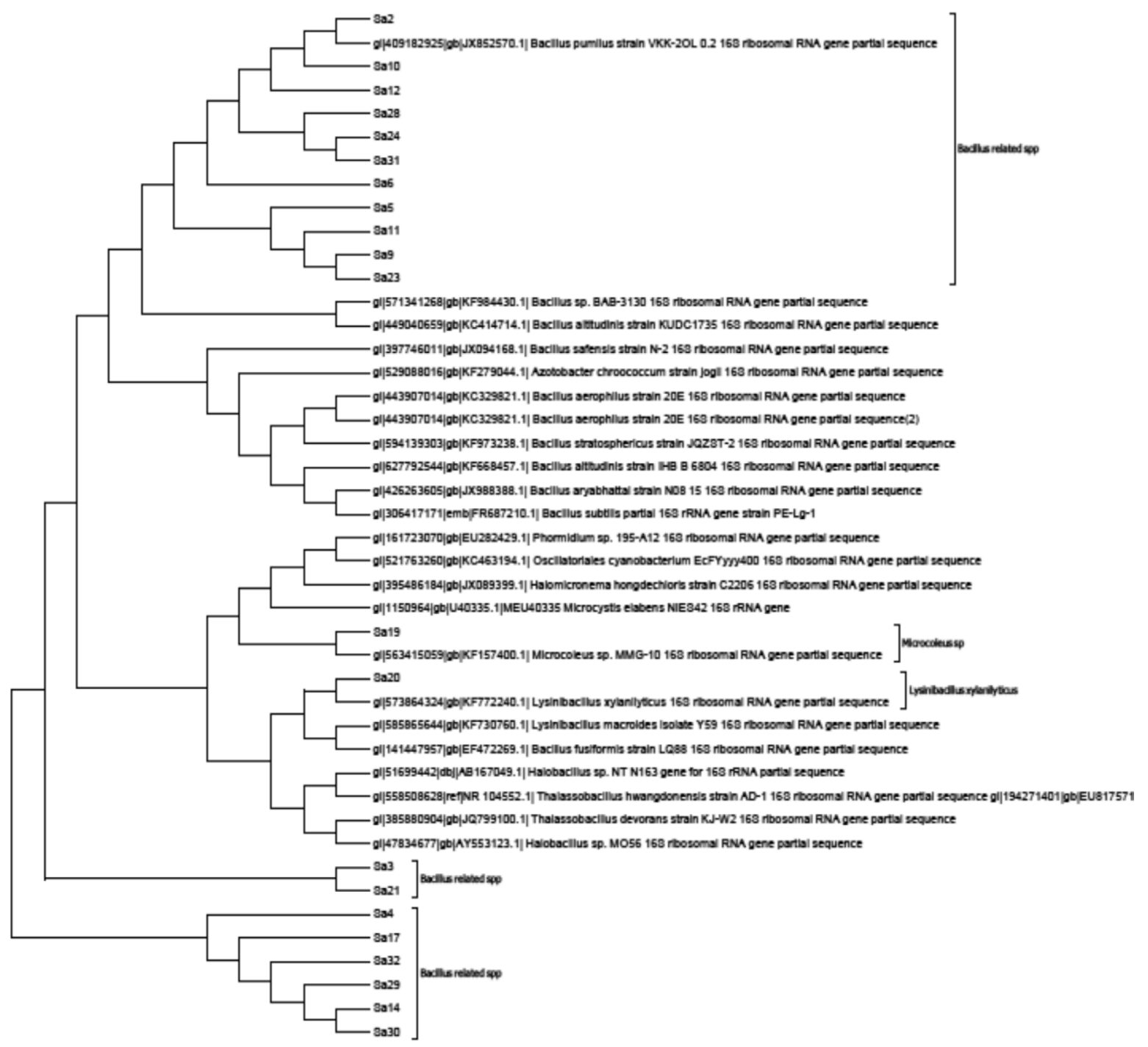

Figure 5: Unrooted phylogenetic tree showing affiliation of bacterial and cyanobacteria consortium based on partial 165 rRNA sequences. 
Citation: Tersagh I, Ebah EE, Azua ET (2016) Aerobic Degradation of Fluoranthene, Benzo(b)Fluoranthene and Benzo(k)Fluoranthene by Aerobic Heterotrophic Bacteria- Cyanobacteria Interaction in Brackish Water of Bodo Creek. J Pet Environ Biotechnol 7: 292. doi: 10.4172/21577463.1000292

Page 5 of 6

GC-MS. The resident bacteria, cyanobacteria and the consortium mineralized the PAHs studied with observed fluctuations in quantity for benzo(b)fluoranthene and benzo(k)fluoranthene. The observed fluctuation could be as a result of novel synthesis where more complex components of PAHs in the petroleum hydrocarbons may have been metabolized to simpler molecules during biodegradation. Formation of metabolites of benzo(b)fluoranthene and benzo(k)fluoranthene can also account for the fluctuation. Ichor et al. [1] reported similar a trend of fluctuation during phenanthrene degradation without nutritional amendment by aerobic heterotrophic bacteria, cyanobacteria and a consortium of aerobic heterotrophic bacteria and cyanobacteria in petroleum hydrocarbon contaminated Bodo creek throughout the period monitored.

Reports from previous studies had shown the capability of microorganisms to effectively degrade components of poly aromatic hydrocarbon in this study. Forinstance, Maeda et al. [24] reported on transformation of Benzo(k)fluoranthene into four, three and two aromatic ring products after exposure to Sphingobium sp strain KK22. Degradation of Benzo(k)fluoranthene achieved 10\% biotransformation in the first five days and between this to 10 days biodegradation continued with approximately $73 \%$ of Benzo(k)fluoranthene recovered from culture media on the tenth day though it did not support the growth of strain KK22 as a sole source of carbon and energy. Concentration of Benzo(k)fluoranthene reduced by $70 \%$ over an experiment that spanned for 20 days. The genus of Bacillus species; Bacillus firmus remarkably degraded Benzo(b)fluoranthene completely [37] Bacillus subtilis completely degraded Benzo(b)fluoranthene [9]; Psudomonas alcaligenes degraded Benzo(b)fluoranthene among other HMW-PAHs [38].

Ogbonna et al. [39] reported on biodegradation of benzo(b) fluoranthene, benzo(k)fluoranthene and other individual polycyclic aromatic hydrocarbons by a mixed culture of Pseudomonas sp., Bacillus sp. and Klebsiella sp. Microbial degradation contributes significantly to the ultimate removal of organic molecules including oil from soil, freshwater, brackish water and marine environments [40].

Fluoranthene however disappeared after the first week of sampling and was not detected for the rest of the period sampled. Fluoranthene reportedly served as a growth substrate for Alcaligenes denitrificans at the rate of $0.033 / \mathrm{h}$ in previous findings of Weissenfeils et al. [11]. Exponential growth of Mycobacterium strain BB1 grew slower on fluoranthene though it has higher solubility when compared to pyrene but stopped before fluoranthene was completely degraded. Kumar [41] reported invitro degradation of fluoranthene by four bacterial strains which growth invariably corresponded to the degradation potential of fluoranthene. After $168 \mathrm{~h}$ of incubation, $61 \%, 48 \%, 42 \%$ and $41 \%$ of fluoranthene was reportedly degraded by PSM 11, PSM 10, PSM 6, and PSM 7 respectively. Nwinyi et al. [42] reported loss of fluoranthene by 7-19\% during aerobic degradation by Enterobacter and Pseudomonas strains. Cao et al. [43] isolated Celeribacter indicus P73T; which is reportedly the first fluoranthene degrading bacterium within the family of Rhodobacteriaceae.

The observed degradation of fluoranthene, benzo(b)fluoranthene and benzo(k)fluoranthene as reported in this study is sufficient evidence that aerobic heterotrophic bacteria, cyanobacteria and a consortium of aerobic heterotrophic bacteria and cyanobacteria resident in crude oil contaminated and the uncontaminated Bodo creek used as control are inherently capable of biodegrading petroleum hydrocarbons. The observed degradation was carried out without nutrient amendment or biostimulation which is suggested for further field application [44-47].

\section{Conclusion}

The resident aerobic heterotrophic bacteria, cyanobacteria, the consortium and control were capable of degrading fluoranthene, benzo(b)fluoranthene and benzo(k)fluoranthene in brackish waters of Bodo creek. The study proved that the resident flora have inherent abilities for PAHs degradation under moderate salt conditions without nutrient amendment, thus providing evidence of the presence of PAHs degrading halo-tolerant bacteria and cyanobacteria under moderate salt conditions.

\section{References}

1. Ichor T, Okerentugba PO, Okpokwasili GC (2016) Biodegradation of total petroleum hydrocarbon by a consortium of cyanobacteria isolated from crude oil polluted brackish waters of Bodo creeks in Ogoniland, rivers state. Research Journal of Environmental Toxicology 10: 16-27.

2. Kweon O, Kim SJ, Holland RD, Chen H, Kim DW, et al. (2011) Polycyclic aromatic hydrocarbon metabolic network in Mycobacterium vanbaalenii PYR1. J Bacteriol 193: 4326-4337.

3. Mishra S, Singh SN, Pande V (2014) Bacteria induced degradation of flouroethane in minimal salt medium mediated by catabolic enzymes in vitro condition. Bioresource technology 164: 299-308.

4. Yu H, Zhu L, Zhou W (2007) Enhanced desorption and biodegradation of phenanthrene in soil-water systems with the presence of anionic-nonionic mixed surfactants. J Hazard Mater 142: 354-361.

5. Kanaly RA, Harayama S (2000) Biodegradation of high-molecular-weight polycyclic aromatic hydrocarbons by bacteria. J Bacteriol 182: 2059-2067.

6. Lafortune I, Juteau P, Déziel E, Lépine F, Beaudet R (2009) Bacteria diversity of a consortium degrading high-molecular-weight polycyclic aromatic hydrocarbons in a two-liquid phase biosystem. Microb Ecol 57: 455-468.

7. Burchiel SW, Luster MI (2001) Signaling by environmental polycyclic aromatic hydrocarbons in human lymphocytes. Clin Immunol 98: 2-10.

8. Van de Wiele T, Vanhaecke L, Boeckaert C, Peru K, Headley J, et al. (2005) Human colon microbiota transform polycyclic aromatic hydrocarbons to estrogenic metabolites. Environ Health Perspect 113: 6-10.

9. Magyarosy N (2002) Environmental indicators. In Armon RH, Hanninen O (eds).

10. Meador JP (2003) Bioaccumulation of PAHS in marine invertebrates. In Douben PET (ed). John Wiley \& Sons pp. 147-171

11. Weissenfels WD, Beyer M, Klein J (1990) Degradation of phenanthrene, fluorene and fluoranthene by pure bacterial cultures. Appl Microbiol Biotechnol 32: 479-484.

12. Juhasz AL, Britz ML, Stanley GA (1997) Degradation of fluoranthene, pyrene, benz(a)anthracene and dibenz(a,h)anthracene by Burkholderia cepacia. J Appl Microbiol 83: 189-198.

13. Lee SE, Seo JS, Keum YS, Lee KJ, Li QX (2007) Fluoranthene metabolism and associated proteins in Mycobacterium sp. JS14. Proteomics 7: 2059-2069.

14. Gordon L, Dobson AD (2001) Fluoranthene degradation in Pseudomonas alcaligenes PA-10. Biodegradation 12: 393-400.

15. Walter U, Beyer M, Klein J, Rehm HJ (1991) Degradation of pyrene by Rhodococcus sp. UW1. Appl Microbiol Biotechnol 34: 671-676.

16. Baboshin M, Akimov V, Baskunov B, Born TL, Khan SU, et al. (2008) Conversion of polycyclic aromatic hydrocarbons by Sphingomonas sp. VKM B-2434. Biodegradation 19: 567-576.

17. Wu Y, He T, Zhong M, Zhang Y, Li E, et al. (2009) Isolation of marine benzo(a) pyrene-degrading Ochrobactrum sp. BAP5 and proteins characterization. Environ Sci (China) 21: 1446-1451.

18. Yuan J, Lai Q, Zheng T, Shao Z (2009) Novosphingobium indicum sp. nov., A polycyclic aromatic hydrocarbon-degrading bacterium isolated from a deep-sea environment. Int J Syst Evol Microbiol 59 2084-2088.

19. Geiselbrecht AD, Hedlund BP, Tichi MA, Staley JT (1998) Isolation of marine polycyclic aromatic hydrocarbon ( $\mathrm{PAH}$ )-degrading Cycloclasticus strains from the Gulf of Mexico and comparison of their PAH degradation ability with that of puget sound Cycloclasticus strains. Appl Environ Microbiol 64: 4703-4710. 
Citation: Tersagh I, Ebah EE, Azua ET (2016) Aerobic Degradation of Fluoranthene, Benzo(b)Fluoranthene and Benzo(k)Fluoranthene by Aerobic Heterotrophic Bacteria- Cyanobacteria Interaction in Brackish Water of Bodo Creek. J Pet Environ Biotechnol 7: 292. doi: 10.4172/21577463.1000292

20. Lai Q, Cao J, Yuan J, Li F, Shao Z (2014) Celeribacter indicus sp. nov., A polycyclic aromatic hydrocarbon-degrading bacterium from deep-sea sedimen and reclassification of Huaishuia halophila as Celeribacter halophilus comb. nov. Int J Syst Evol Microbiol 64: 4160-4167.

21. Dean-Ross D, Moody J, Cerniglia CE (2002) Utilization of mixtures of polycyclic aromatic hydrocarbons by bacteria isolated from contaminated sediment. FEMS Microbiol Ecol 41: 1-7.

22. Al-Mailem DM, Eliyas M, Radwan S (2013) Oil-bioremediation potential of two hydrocarbonoclastic, diazotrophic Marinobacter strains from hypersaline areas along the Arabian Gulf coasts. Extremophiles 17: 463-470.

23. Dastgheib SM, Amoozegar MA, Khajeh K, Shavandi M, Ventosa A (2012) Biodegradation of polycyclic aromatic hydrocarbons by a halophilic microbia consortium. Appl Microbiol Biotechnol 95: 789-798.

24. Maeda AH, Shinro N, Yuji H, Yasuhiro O, Robert AK (2014) Biotransformation of the high-molecular weight polycyclic aromatic hydrocarbon (PAH) benzo(k) fluoranthene by Sphingobium sp. strain KK22 and identification of new products of non-alternant PAH biodegradation by liquid chromatography electrospray ionization tandem mass spectrometry. Microb Biotechnol 7: 114-129

25. Cerniglia CE (1992) Biodegradation of polycyclic aromatic hydrocarbons Biodegradation 3: 351-368.

26. De Maagd P, Ten Hulscher DTEM, Van De Heuvel H, Opperhuizen A, Sijm DTHM (1998) Physiochemical properties of polycyclic aromatic hydrocarbons: aqueous solubilities, n-octanol/water partition coefficients, and Henry's Law constants. Environ Toxicol Chem 17: 251-257.

27. Sverdrup LE, Nielsen T, Krogh PH (2002) Soil ecotoxicity of polycyclic aromatic hydrocarbons in relation to soil sorption, lipophilicity, and water solubility. Environ Sci Technol 36: 2429-2435

28. Li X, Li P, Lin X, Zhang C, Li Q, et al. (2008) Biodegradation of aged polycyclic aromatic hydrocarbons (PAHs) by microbial consortia in soil and slurry phases. J Hazard Mater 150: 21-26.

29. Wang J, Xu H. An M, Yan G (2008) Kinetics and characteristics of phenanthrene degradation by a microbial consortium. Petrol Sci 5: 73-78.

30. Achten C, Cheng S, Straub KL, Hofmann T (2011) The lack of microbial degradation of polycyclic aromatic hydrocarbons from coal-rich soils. Environ Pollut 159: 623-629.

31. Lladó S, Covino S, Solanas A, Viñas M, Petruccioli M (2013) Comparative assessment of bioremediation approaches to highly recalcitrant $\mathrm{PAH}$ degradation in a real industrial polluted soil. J Hazard Mater 248: 407-414.

32. Boström CE, Gerde P, Hanberg A, Jernström B, Johansson C, et al (2002) Cancer risk assessment, indicators, and guidelines for polycyclic aromatic hydrocarbons in the ambient air. Environ Health Perspect 110 Suppl 3: 451-488.

33. Zheng Z, Obbard JP (2002) Polycyclic aromatic hydrocarbon removal from soil by surfactant solubilization and Phanerochaete chrysosporium oxidation. J Environ Qual 31: 1842-1847.
34. Zheng Z, Obbard JP (2003) Oxidation of polycyclic aromatic hydrocarbons by fungal isolates from an oil contaminated refinery soil. Environ Sci Pollut Res Int 10: 173-176.

35. Cerniglia CE (1997) Fungal metabolism of polycyclic aromatic hydrocarbons: past, present and future applications in bioremediation. J Ind Microbio Biotechnol 19: 324-333.

36. Ichor T, Okerentugba PO, Okpokwasili GC (2014) Biodegradation of total petroleum hydrocarbon by aerobic heterotrophic bacteria isolated from crude oil contaminated brackish waters of Bodo creek. Journal of Bioremediation and Biodegradation 5: 5 .

37. Schneider J, Grosser R, Jayasimhulu K, Xue W, Warsha D (1996) Degradation of Pyrene, benz(a)anthracene and benzo(a)pyrene by Mycobacterium spp strain, RJG 11-135. Isolated from a former coal gasification site. Appl Environ microbial 62: 13-19.

38. Bjorklof K, Karlsson S, Frostegard A, Jorgensen KS (2009) Presence of antibacterial and antifungal communities in clean and petroleum hydrocarbon contaminated subsurface soil. Open Microbiol J 3: 75-86.

39. Ogbonna DN, Ideriah TJK, Nwachukwu MI (2012) Biodegradation of polycyclic aromatic hydrocarbons by associated microbes from abattoir wastes in the Niger Delta, Nigeria. Journal of Microbiology Research 2: 157-169.

40. Amanchukwu SC, Obafemi A, Okpokwasili GC (1986) Hydrocarbon degradation and utilization by a palmwine yeast isolate. FEMS Microbiol. Lett. 57: 151-154.

41. Kumar V, Kothiyal NC (2011) Distribution behaviour of polycyclic aromatic hydrocarbons in roadside soil at traffic intercepts within developing cities. International Journal of Environmental Science and Technology 8: 63-72.

42. Nwinyi OC, Flynn W, Thuy T, Olukayode O (2013) Aerobic degradation of naphthalene, fluoranthene, pyrene and chrysene using indigenous strains of bacteria isolated from a former industrial site. Canadian Journal of pure and applied Sciences 7: 2303-2314

43. Cao J, Lai Q, Yuan J, Shao Z (2015) Genomic and metabolic analysis of fluoranthene degradation pathway in Celeribacter indicus P73T. Sci Rep 5: 7741

44. Lai Q, Cao J, Yuan J, Li F, Shao Z (2014) Celeribacter indicus sp. nov., A polycyclic aromatic hydrocarbon-degrading bacterium from deep-sea sediment and reclassification of Huaishuia halophila as Celeribacter halophilus comb. nov. Int J Syst Evol Microbiol 64: 4160-4167

45. Jerry NM (2003) Bioaccumulation in marine organisms-effect of contaminants from oil well produced water. Journal of Experimental Marine Biology and Ecology 287: 135-137

46. Salleh AB, Ghazali MF, Zaliha NR, Basri M (2003) Bioremediation of petroleum hydrocarbon pollution. Indian Journal of Biotechnology 2: 411-425.

47. Cui Z, Xu G, Li Q, Gao W, Zheng L (2013) Genome sequence of the pyreneand fluoranthene-degrading bacterium Cycloclasticus sp. strain PY97M Genome Announc 1. 